\title{
The Composition of Serous Fluid after Axillary Dissection
}

\author{
Jorien Bonnema, ${ }^{1,2}$ David A. Ligtenstein, ${ }^{1}$ Theo Wiggers ${ }^{1,2}$ and Albert N. van Geel ${ }^{1,2}$ \\ From the ${ }^{1}$ Department of Surgical Oncology, University Hospital Rotterdam/Daniel den Hoed Cancer Center and \\ 2Zuider Hospital, Rotterdam, The Netherlands
}

Eur J Surg 1999; 165: 9-13

\begin{abstract}
Objective: To analyse the composition of the serous fluid formed after axillary dissection Design: Descriptive study

Setting: University hospital and teaching hospital, The Netherlands

Subjects: 16 patients whose axillas were dissected as part of a modified radical mastectomy for stage I or II breast cancer Main outcome measures: Chemical and cellular composition of axillary drainage fluid on the first, fifth, and tenth postoperative days compared with the same constituents in blood and with reported data on the composition of peripheral lymph.

Results and conclusion: On the first postoperative day the drainage fluid contained blood contents and a high concentration of creatine phosphokinase (CPK). After day one it changed to a peripheral lymph-like fluid but containing different cells, more protein, and no fibrinogen, making coagulation impossible. The reduction in the fluid production must be caused by other wound healing processes, such as formation of scars and connective tissue.
\end{abstract}

Key words: axillary dissection, breast cancer, composition of drainage fluid.

\section{INTRODUCTION}

Non-haemorrhagic fluid commonly forms in wounds after the dissection of axillary nodes and the collection is known as a seroma. The origin of this fluid is not well understood and studies on its origin and composition are scarce (28). The name suggests that the fluid originates from ultrafiltration of blood. Other explanations for its formation are leakage of lymph from disrupted lymphatics in the axilla $(24,27)$ and the production of a wound exudate as part of the inflammatory phase of wound healing (28).

We studied the composition of the fluid formed in the axilla after dissection of axillary lymph nodes and compared the results with the composition of blood of the same patients and with reported data on the composition of peripheral lymph. To distinguish it from chyle, which can be sampled from the thoracic duct, we use the term peripheral lymph, which is lymph produced in the extremities and has not yet passed through a node or come into contact with other lymphoid structures (29). The aim of the study was to analyse the chemical and cellular composition of serous fluid from the axilla to shed some light on the processes involved in its formation.

\section{PATIENTS AND METHODS}

Sixteen patients with breast cancer underwent axillary dissection as part of a modified radical mastectomy as prescribed by Madden (19). Criteria for exclusion were the use of corticosteroids or anticoagulants, preoperative radiotherapy or chemotherapy, and postoperative hematoma or infection. Level I, II and III nodes were resected. Low-dose heparin was used for prophylaxis of deep venous thrombosis. The axilla was drained with a closed suction drainage system. A separate drain was used for the skin flaps of the mastectomy wound. Drains were removed if less than $30 \mathrm{ml}$ of fluid was produced on two consecutive days. Samples of the axillary drainage fluid were obtained on the first, fifth, and tenth postoperative days. On the first postoperative day a blood sample was also taken. The fluids were assayed in the clinical laboratory of the Zuider Hospital. Concentrations of the following substances were measured: electrolytes - sodium, potassium, calcium, magnesium, phosphate and iron; proteins - total protein and albumin; electrophoresis- $\alpha-1$ globulins, $\alpha-2$ globulins, $\beta$ globulins and gamma globulins; haemoglobin, transferrin, IgG, and fibrinogen; lipids - triglycerides and cholesterol; cells-platelets, red cells and leucocytes; and glucose, osmolality and creatine phosphokinase (CPK).

The mean values of the variables in blood and drainage fluid were compared by independent group analysis using a Tukey non-parametric multiple comparison test. Statistical analyses were done on a personal computer using the Kwikstat version 4.1 
Table 1. Mean (SEM) concentrations of constituents of serous fluid after axillary dissection

\begin{tabular}{|c|c|c|c|c|c|}
\hline \multirow[b]{2}{*}{ Variable } & \multirow[b]{2}{*}{$\begin{array}{l}\text { Blood } \\
(n=16)\end{array}$} & \multicolumn{3}{|l|}{ Serous fluid } & \multirow[b]{2}{*}{ Comment* } \\
\hline & & $\begin{array}{l}\text { Day } 1 \\
(n=16)\end{array}$ & $\begin{array}{l}\text { Day } 5 \\
(n=14)\end{array}$ & $\begin{array}{l}\text { Day } 10 \\
(n=5)\end{array}$ & \\
\hline \multicolumn{6}{|l|}{ Electrolytes } \\
\hline Sodium (mmol/L) & $141.3(0.7)$ & $140.1(0.6)$ & $141.3(0.5)$ & $140.2(1.4)$ & No differences. \\
\hline Potassium (mmol/L) & $3.9(0.1)$ & $4.3(0.1)$ & $4.2(0.1)$ & $4.3(0.1)$ & No differences. \\
\hline Calcium (mmol/L) & $2.26(0.03)$ & $1.87(0.04)$ & $1.90(0.03)$ & $1.94(0.04)$ & Serous fluid lower than blood. \\
\hline Magnesium (mmol/L) & $0.75(0.02)$ & $0.80(0.03)$ & $0.74(0.01)$ & $0.78(0.02) \quad \mathrm{l}$ & No differences. \\
\hline Phosphate $(\mathrm{mmol} / \mathrm{L})$ & $0.95(0.05)$ & $1.23(0.12)$ & $1.13(0.06)$ & $1.15(0.08) \quad \mathrm{l}$ & No differences. \\
\hline Iron $(\mu \mathrm{mol} / \mathrm{L})$ & $10.9(1.0)$ & $25.4(2.9)$ & $13.1(1.2)$ & $14.4(2.7)$ & $\begin{array}{l}\text { Serous fluid day } 1 \text { higher } \\
\text { than other values. }\end{array}$ \\
\hline \multicolumn{6}{|l|}{ Proteins } \\
\hline Total protein (g/L) & $57.7(1.3)$ & $42.8(2.5)$ & $37.0(1.2)$ & $39.2(1.6)$ & Serous fluid lower than blood. \\
\hline Albumin $(\mathrm{g} / \mathrm{L})$ & $33.8(1.0)$ & $23.2(1.1)$ & $24.6(1.0)$ & $26.0(1.7)$ & Serous fluid lower than blood. \\
\hline Alpha-1 globulins (g/L) & $3.17(0.18)$ & $1.51(0.15)$ & $1.53(0.15)$ & $1.48(0.10)$ & Serous fluid lower than blood. \\
\hline Alpha-2 globulins (g/L) & $5.8(0.2)$ & $2.6(0.3)$ & $2.4(0.2)$ & $2.3(0.3)$ & Serous fluid lower than blood. \\
\hline Beta globulins $(\mathrm{g} / \mathrm{L})$ & $7.3(0.3)$ & $8.3(1.5)$ & $3.5(0.3)$ & $4.5(0.4)$ & $\begin{array}{l}\text { No difference serous fluid } \\
\text { day } 1 \text { and blood. }\end{array}$ \\
\hline Gamma globulins (g/L) & $8.1(0.5)$ & $5.2(0.3)$ & $4.1(0.3)$ & $5.0(0.5)$ & Serous fluid lower than blood. \\
\hline Immunoglobulins $\mathrm{G}(\mathrm{g} / \mathrm{L})$ & $8.5(0.6)$ & $4.9(0.3)$ & $4.6(0.3)$ & $5.2(0.6)$ & Serous fluid lower than blood. \\
\hline Haemoglobin $(\mathrm{mmol} / \mathrm{L})$ & $7.79(0.24)$ & $1.74(0.40)$ & $0.25(0.09)$ & Trace & $\begin{array}{l}\text { Serous fluid lower than } \\
\text { blood. Rapid decline. }\end{array}$ \\
\hline Transferrin $(\mu \mathrm{mol} / \mathrm{L})$ & $54.1(2.9)$ & $32.5(2.0)$ & $32.0(2.0)$ & $31.4(1.7)$ & Serous fluid lower than blood. \\
\hline Fibrinogen $(\mathrm{g} / \mathrm{L})$ & $3.07(0.21)$ & $0.15(0.02)$ & $0.13(0.02)$ & Trace & Serous fluid lower than blood. \\
\hline \multicolumn{6}{|l|}{ Lipids } \\
\hline Triglycerides $(\mathrm{mmol} / \mathrm{L})$ & $1.92(0.50)$ & $1.42(0.21)$ & $0.60(0.06)$ & $0.46(0.05)$ & $\begin{array}{l}\text { No difference serous fluid } \\
\text { day } 1 \text { and blood. }\end{array}$ \\
\hline Cholesterol (mmol/L) & $4.6(0.4)$ & $2.4(0.2)$ & $1.8(0.1)$ & $2.1(0.3)$ & Serous fluid lower than blood. \\
\hline \multicolumn{6}{|l|}{ Cells } \\
\hline Platelets $\left(\times 10^{9} / \mathrm{L}\right)$ & $248(15)$ & $64(10)$ & $21(5)$ & $16(4)$ & $\begin{array}{l}\text { Serous fluid lower than } \\
\text { blood. Rapid decline. }\end{array}$ \\
\hline Red cells $\left(\times 10^{12} / \mathrm{L}\right)$ & $4.1(0.1)$ & $1.1(0.2)$ & $0.1(0.04)$ & Trace & $\begin{array}{l}\text { Serous fluid lower than } \\
\text { blood. Rapid decline. }\end{array}$ \\
\hline Leucocytes $\left(\times 10^{9} / \mathrm{L}\right)$ & $10.1(1.0)$ & $10.6(1.5)$ & $1.3(0.3)$ & $0.3(0.2)$ & $\begin{array}{l}\text { No difference serous fluid } \\
\text { day } 1 \text { and blood. }\end{array}$ \\
\hline \multicolumn{6}{|l|}{ Differentiation } \\
\hline Neutrophils (\%) & $72.2(3.2)$ & $93(1.8)$ & Not measurable & Not measurable & \\
\hline Lymphocytes (\%) & $22.2(2.9)$ & $6(1.6)$ & Not measurable & Not measurable & \\
\hline Monocytes (\%) & $5.6(1.2)$ & $1(0.6)$ & Not measurable & Not measurable & \\
\hline $\begin{array}{l}\text { Eosinophils and } \\
\text { basophils (\%) }\end{array}$ & $0.8(0.05)$ & $0.1(0.02)$ & Not measurable & Not measurable & \\
\hline \multicolumn{6}{|l|}{ Other } \\
\hline Glucose $(\mathrm{mmol} / \mathrm{L})$ & $4.0(0.05)$ & $4.2(0.3)$ & $3.9(0.1)$ & $4.2(0.2)$ & No differences. \\
\hline Osmolality (mOsm/L) & $296(3)$ & $290(2)$ & $292(2)$ & $302(10)$ & No differences. \\
\hline CPK (E/L) & $223(62)$ & $22600(3800)$ & $2750(1800)$ & $75(13)$ & $\begin{array}{l}\text { Extreme increase after operation } \\
\text { then rapid decline }\end{array}$ \\
\hline
\end{tabular}

* All differences statistical significant with $p<0.001$. Tukey multiple comparison test.

statistical data analysis package (TexaSoft, Cedar Hill, Texas, USA).

\section{RESULTS}

Results of the analyses are shown in Table 1. No patients had intermittent fluid formation, and no patients had to be excluded because they produced too little or no fluid.

The values of electrolytes in serous fluid were lower for calcium compared with blood. The calcium:albumin ratio was 0.080 for serous fluid and 0.067 for blood. The iron content was high on day 1 in serous fluid which was also iso-osmotic (290 mOsm). Concentrations of CPK in serous fluid were extremely high 
on day 1. Concentrations of all proteins were significantly lower in serous fluid compared with blood with the exception of $\beta$ globulin, which did not differ on day 1 . Only very small amounts of fibrinogen were found in the serous fluid. Red cells, platelets and leucocytes were present in the fluid on day 1, but had nearly gone on days 5 and 10 . The serous fluid:blood ratio on day 1 was similar for red cells and platelets (0.26), but was much higher for leucocytes (1.05). Differentiation of the leucocytes on day 1 showed $93 \%$ neutrophils, $6 \%$ lymphocytes, and $1 \%$ monocytes.

\section{DISCUSSION}

Obviously during the first days the drainage fluid is contaminated with blood from the surgical wound, so iron, triglycerides, haemoglobin, and blood cells are present in the fluid on day 1 . They disappear rapidly thereafter. The same goes for CPK, the presence of which may be attributed to tissue destruction as a direct result of the operation. In addition, the fluid is isoosmotic. The presence of fibrinogen from blood may lead to the formation of some clots early in the wound healing process, but later on, when the fibrinogen originating from blood has been used up, this ceases.

Once constituents of blood have disappeared concentrations of electrolytes and glucose in the serous fluid are similar to those in serum, with the exception of calcium. For sodium, potassium, magnesium, phosphate, and calcium the reported concentrations in lymph $(5,17,21,23,29)$ are similar to those we found in serous fluid. Iron is present in large quantities on the first day, probably as a result of decomposition of haemoglobin.

Concentrations of protein in the serous fluid are lower than in plasma, but somewhat higher than in peripheral lymph $(10,14,18,21,25,26)$. There is no relation with the molecular weight of the proteins, and there is no development over time.

What is striking about the fluid formed in the axilla is the almost complete absence of fibrinogen. As a consequence of this, it does not clot spontaneously so clotting cannot be the cause of the reduced production of fluid over time. This must, therefore, be caused by other processes such as the formation of collagen and connective tissue. This accords with the low concentration of coagulation factors that is found in peripheral lymph in animal studies $(7,16)$. In humans fibrinogen can be measured only in thoracic duct lymph, in which concentrations vary (9).

It has been suggested that the sealing of ruptured lymphatics by the coagulation of lymph is an important factor in the eventual cessation of leakage of lymph after pelvic lymphadenectomy. This process may be slowed down by the use of low-dose heparin. (8). The absence of fibrinogen in fluid from the axilla makes such a mechanism for the cessation of the production of fluid unlikely. The mechanism by which tranexamic acid acts in reducing the volume of axillary fluid production, as reported recently (20), therefore remains obscure (4).

The fluid in the axilla is cell-deficient. It contains mainly leucocytes on day one, but the concentration of cells rapidly declines with time. Granulocytes were the dominant leucocytes, but we saw no shift to lymphocytes such as was reported in a previous study to be associated with the exudative phase of wound healing (28). Peripheral lymph contains appreciable counts of lymphocytes $(12,13,23,26,29)$, no platelets (15) and, like serous fluid, only few red cells $(12,23,29)$.

Some aspects on the composition of serous fluid need further investigation, such as its role in wound healing and the problem of protracted seroma formation after removal of the drain. The presence of a seroma is considered to be a risk factor for wound infection. Wound fluid collected from patients after modified radical mastectomy impaired the neutrophildependent killing of bacteria because of a deficiency in the normal humoral factors such as complement and fibronectin (6). The loss of opsonic activity of plasma proteins in wound fluids progresses over time (3). We found low concentrations of albumin and transferrin in the drainage fluid, which may contribute to the inability of the fluid to support lymphocyte blastogenesis to the same extent as serum, a process necessary for wound healing. This topic needs further elucidation in future studies.

The development of seroma fluid around a prosthetic graft in reconstructive vascular surgery is associated with the presence of a fibroblast inhibitor in serum (1), recently identified as a protein with a molecular weight of $2000 \mathrm{Da}$. (2). Fibroblast inhibitors with low molecular weights are also found in wound fluids and may very well be part of a physiological regulatory mechanism in wound healing (22). Macrophages have a role in the production of these inhibitors (11). It is still too early to speculate about the role of inhibition of fibroblast growth as a factor in protracted seroma production as happens in some patients after surgery for breast cancer.

In conclusion, the serous fluid formed in the axilla after lymph node dissection seems to be a peripheral lymph-like fluid. However, the cell content is somewhat different from that of lymph, and it contains no fibrinogen. Initially postoperatively the composition of the fluid includes blood components, but these disappear rapidly thereafter. The absence of fibrinogen, precluding the coagulation of the fluid, has important consequences for the process responsible for the ultimate cessation of seroma production. The fluid 
shares little resemblance with a wound exudate, because of the low concentration of cells, absence of fibrinogen, and the low protein content.

\section{ACKNOWLEDGEMENTS}

We thank Dr M. J. Mantel and Dr R. W. Wulkan, clinical biochemists of the Zuider Hospital, for doing the assays in their laboratory and commenting on the results.

\section{REFERENCES}

1. Ahn SS, Machleder HI, Gupta R, et al. Perigraft seroma: clinical, histological and serologic correlates. Am J Surg 1987; 154: 173-178.

2. Ahn SS, Williams DE, Thye DA, Cheng KQ, Lee DA. The isolation of a fibroblast growth inhibitor associated with perigraft seroma. J Vasc Surg 1994; 20: 202-208.

3. Alexander JW, Korelitz J, Alexander NS. Prevention of wound infections: A case for closed suction drainage to remove wound fluids deficient in opsonic proteins. Am J Surg 1976; 132: 59-63.

4. Bonnema J, van Geel AN, Wiggers T, Ligtenstein DA. Perioperative and postoperative tranexamic acid reduces the local wound complication rate after surgery for breast cancer. Br J Surg 1994; 81: 1693 (Letter).

5. Braun WE, Banowsky LH, Straffon RA, et al. Lymphoceles associated with renal transplantation. Am J Med 1974; 57: 714-729.

6. Bridges M, Morris D, Hall JR, Deitch EA. Effects of wound exudates on in vitro immune parameters. J Surg Res 1987; 43: 133-138.

7. Brinkhous KM, Walker SA. Prothrombin and fibrinogen in lymph. Am J Physiol 1941; 132: 666-669.

8. Catalona WL, Kadmon D, Crane DB. Effect of minidose heparin on lymphocele formation following extraperitoneal pelvic lymphadenectomy. J Urol 1980; 123: 890-892.

9. Chrobak L, Bartos V, Brzek V, Hnizdora D. Coagulation properties of human thoracic duct lymph. Am J Med Sci 1967; 253: 69.

10. Coates G, O'Brodovich H, Goeree G. Hindlimb and lung lymph flows during prolonged exercise. J Appl Physiol 1993; 75: 633-638.

11. Concannon MJ, Barrett BB, Adelstein EH, Thornton WH, Puckett CL. The inhibition of fibroblast proliferation by a novel monokine: an in vitro and in vivo study. J Burn Care Rehab 1993; 14: 141-147.

12. de Hert S, Heytens L, van Hee R, Adriaensen H. Current management of traumatic chylothorax. Acta Anaesth Belg 1988; 39: 101-107.

13. Engeset A, Hager B, Nesheim A, Kolbenstvedt A. Studies on human peripheral lymph. Lymphology 1973; 6: 1-5.

14. Engeset A, Olszelwski W, Jaeger PM, Sokolowski J, Theodorsen L. Twenty-four hour variation in flow and composition of leg lymph in normal men. Acta Physiol Scand 1977; 99: 140-148.

15. Fantl P, Nelson JF. Coagulation in lymph. J Physiol 1953; 122: 33-37.

16. Kaulla KN, Pratt EB. Influence of intravenously administered heparin on clotting of lymph in the dog. Am J Physiol 1956; 187: 89-93.
17. Keyl MJ, Dowell RT, Yunice AA. Comparison of renal and cardiac lymph constituents. Lymphology 1980; 13: $158-160$.

18. Lewis GP, Winsey NJP. The action of pharmacologically active substances on the flow and composition of cat hind limb lymph. Br J Pharmacol 1970; 40: 446-460.

19. Madden JL. Modified radical mastectomy. Surg Gynecol Obstet 1965; 121: 1221-1230.

20. Oertli D, Laffer U, Haberthuer F, Kreuter U, Harder F. Perioperative and postoperative tranexamic acid reduces the local wound complication rate after surgery for breast cancer. Br J Surg 1994; 81: 856-859.

21. Physical properties and chemical composition of lymph. In: Altman PL, Dittmer DS, eds. Mammals, blood and other body fluids. Bethesda: Federation of American Societies for Experimental Biology, 1971: 307-312.

22. Pricolo VE, Caldwell MD, Mastrofrancesco B, Mills CD. Modulatory activities of wound fluid on fibroblast proliferation and collagen synthesis. J Surg Res 1990; 48: 534-538.

23. Robinson CLN. The management of chylothorax. Ann Thorac Surg 1985; 39: 90-95.

24. Sitzmann JV, Dufresne C, Zuidema GD. The use of sclerotherapy for treatment of postmastectomy seromas. Surgery $1983 ; 93: 345-347$.

25. Sloop CH, Castle CK, Lefevre M, Wong L. Comparison of the lipid and lipoprotein composition of skeletal muscle and peripheral lymph in control dogs and in dogs fed with a high fat, high cholesterol, hypothyroid diet. Biochim Biophys Acta 1993; 1169: 196-201.

26. Smith JB, McIntosh GH, Morris B. The traffic of cells through tissues: a study of peripheral lymph in sheep. $\mathrm{J}$ Anat 1970; 107: 87-100.

27. Tadych K, Donegan WL. Postmastecomy seromas and wound drainage. Surg Gynecol Obstet 1987; 165: 483487.

28. Watt-Boolsen S, Nielsen VB, Jensen J, Bak S. Postmastectomy seroma. A study of the nature and origin of seroma after mastectomy. Dan Med Bull 1989; 36: 487-489.

29. Yoffey JM, Courtice FC Lymphatics, lymph and lymphoid tissue, Cambridge: Harvard University Press, 1956.

\section{RÉSUMÉ}

But: Analyser la composition des lymphocèles survenant après dissection du creux axillaire.

Type d'étude: Descriptive.

Provenance: Hôpital universitaire, Pays-Bas.

Patients: Seize patients ayant eu un curage axillaire associé à une mastectomie type Madden pour un cancer du sein stade I ou II.

Principaux critères de jugement: La composition chimique et la cellularité des liquides de drainage axillaire à $\mathrm{J} 1$, J5, et J10 postopératoires comparés aux mêmes paramètres dans le sang et aux données receuillies sur la composition de la lymphe périphérique.

Résultats et conclusions: Le premier jour postopératoire l'épanchement contient du sang et une concentration élevée de créatine phosphokinase (CPK). Après le premier jour il a les caractéristiques d'un épanchement lymphatique périphérique mais contient différentes cellules, plus de protéines, et pas de fibrinogéne, ce qui rend impossible sa coagulation. La diminution de la production de l'épanchement peut être 
obtenue par d'autres processus de cicatrisation, tels que la formation de fibrose et de tissu conjonctif.

Mots-clés: Dissection du creux axillaire, cancer du sein, composition des lymphocèles.

\section{ZUSAMMENFASSUNG}

Ziel: Die Analyse der Zusammensetzung der serösen Flüssigkeit nach Dissektion der Achselhöhle.

Studienanordnung: Deskriptive Studie.

Studienort: Universitätsklinik und Lehrkrankenhaus. Niederlande.

Patienten: 16 Patienten deren Achselhöhlen disseziert worden waren als Teil einer modifizierten radikalen Mastektomie bei Brustkarzinom Stadium I oder II.

Endpunkte: Chemische und zelluläre Komposition der Drainagenflüssigkeit am ersten, fünften und zehnten postoperativen Tag im Vergleich mit den gleichen Komponenten im Blut und Referenzwerten zur Komposition der Lymphe. Ergebnisse und Schlussfolgerung: Am ersten postoperativen Tag besteht die Seromflüssigkeit aus Blut und hat eine hohe Konzentration von Kreatinphosphokinase (CPK). Nach dem ersten Tag verändert sich die Flüssigkeit in eine die periphere Lymphe-ähnliche Flüssigkeit, die verschiedene Zellarten und mehr Protein enthällt. Sie enthällt aber kein Fibrinogen, wodurch die Koagulation unmöglich wird. Die Abnahme der Produktion von Seromflüssigkeit muss daher durch andere Wundheilungsprozesse verursacht werden, wie die Bildung von Narben und Bindegewebe.

\section{РЕЗГОМЕ́}

Цель: Изучение состава серозной жидкости, образующейся после аксиллярной диссекции.

Характер исследования: Описательное исследование. Клиника: Университетский госпиталь и учебный госпиталь, Нидерланды.
Пациенты: 16 пациентов, подвергшихся аксиллярной диссекции в рамках модифицированной радикальной мастэктомии при раке молочной железы I или II стадии.

Задачи исследования: Анализ химического и клеточного состава аксиллярной жидкости из дренажа на 1,5 и 10 день после операции по сравнению с аналогичными параметрами в крови и в лимфе.

Результаты и выводы: В первый день после операции серозная жидкость содержала кровь и высокую концентрацию креатинфосфокиназы. В следующие дни характер дренажного отделяемого соответствовал по своему характеру содержанию в периферической лимфе, однако дренажное отделяемое содержало больше клеток и больше протеина. Не было выявлено наличие фибриногена, что делало коагуляцию невозможной. Уменьшение продукции серозной жидкости свидетельствует о заживлении раны через формирование рубцовых и соединительных тканей.

Ключевые слова: Подмышечная диссекция, рак молочной железы, содержимое серозной жидкости.

Submitted January 21, 1997; submitted after revision August 7, 1997; accepted October 1, 1997

Address for correspondence:

J. Bonnema, M.D.

Department of Surgical Oncology

University Hospital Rotterdam

Daniel den Hoed Cancer Center

P.O. Box 5201

NL-3008 AE Rotterdam

The Netherlands 